\title{
How Corruption is Tolerated in the Greek Public Sector: Toward a Second-Order Theory of Normalization ${ }^{1}$
}

\begin{abstract}
Secrecy and "social cocooning" are critical mechanisms allowing the normalization of corruption within organizations. Less studied are processes of normalization that occur when corruption is an "open secret." Drawing on an empirical study of Greek public-sector organizations, we suggest that a second-order normalization process ensues among non-corrupt onlookers both inside and beyond the organization. What is normalized at this level is not corruption, but its tolerance, which we disaggregate into agent-focused tolerance and structurefocused tolerance. Emphasizing the importance of non-corrupt bystanders, we claim that second-order normalization helps corruption persist in situations where its presence is openly acknowledged. This adds an important new dimension to normalization theory and we unpack its implications for both future research and practice in this area.
\end{abstract}

Keywords: corruption, tolerance, public-sector organizations, normalization, second-order normalization

\footnotetext{
${ }^{1}$ We would like to thank Paul Tracey and three anonymous reviewers for their insightful comments and suggestions.
} 
"The only thing necessary for the triumph of evil is that good men do nothing" (Edmund Burke)

There is almost universal agreement that corruption, which within the Western context is defined as the "misuse of authority for personal, sub-unit or organizational gain" (Ashforth \& Anand, 2003: 2) has a corrosive effect on organizations and their stakeholders. Corruption offends public sensibilities (Palmer, 2013), erodes trust in societal institutions (Sutherland, 1949), imposes extra economic costs (IMF, 2016), damages reputations (Aleksander \& Stachowicz-Stanusch, 2008; Gardberg, Sampath, \& Rahman, 2012), and undermines trust in esteemed industries (Elkind \& McLean, 2004; Toffler \& Reingold, 2004).

However, in spite of these negative consequences of corruption, extant research has found that in many organizations, corruption can somehow come to be considered 'normal.' According to Ashforth and Anand (2003), this occurs in corruption is taken-for-granted, accepted and practiced daily. This can occur when wrongdoing is institutionalized in routines and structures, is rationalized by individuals to absolve themselves of responsibility/guilt and when newcomers are socialized to accept corruption as acceptable and/or necessary. These normalization processes are facilitated by concealment and isolation, where participants are 'socially cocooned' (Greil \& Rudy, 1984) from non-corrupt others, creating a "moral microcosm that likely could not survive outside the organization" (Brief, Buttram, \& Dukerich, 2001: 484). Thus, secrecy is an important variable important for normalizing organizational corruption (Yu, Kang, \& Rhodes, 2018), otherwise it is exposed and a crisis or scandal ensues.

Our paper seeks to address the following problem: how is it possible for normalization to occur when there is little secrecy or concealment, where the public and organizational members are well aware of its presence? In answering this question, we seek to explain address 
a blind spot in the normalization literature. Public-sector organizations in particular are exposed to the public eye (during elections, reviews, etc.) and the existence of corruption may be well-known by a wider audience; yet in some cases (as we will shortly discuss with reference to Greece) organizational actors can continue to engage in corrupt activities on a regular and normal basis. Widespread awareness among non-participants especially, both inside and outside the organization, does not lead to organizational collapse or reform. We seek to explain why this occurs.

We chose the Greek public to do so According to Transparency International (TI) (2019, 2011), a non-governmental organization that monitors corruption internationally, Greece has ranked in the bottom quartile of the Corruption Perception Index (CPI) for EU countries for the period 1995-2019. A similar survey found that the Greek public-sector was considered the most corrupt of the 27 EU member states (BBC, 2012), and in 2011, TI estimated the monetary magnitude of corruption in the Greek public-sector to be 379 million Euros, with $7.4 \%$ of all households being affected (Transparency-International, 2011). Corruption in Greece seems to have been in place for decades, as several studies indicate (Pavlopoulos, 1987; Manesiotis, 1991; Kanellopoulos, Kousoulakos, \& Rapanos, 1995; Tatsos 2001; Kollintzas, 2000). Moreover, Greece combines institutional elements of both developed and developing countries and is thus being pulled in different directions regarding the corruption of its public-sector (Kollintzas, 2000; Blundo, de-Sardan, Arifari, \& Alou, 2013). Greece provides an extreme case (Flyvbjerg, 2006), allowing us to better observe elements and processes linked to our research question. To this end, we collected data from a number of sources, including 58 interviews with managers in the Greek public-sector about their experiences with corruption.

Our findings are somewhat inconsistent with normalization theory. First, corruption in Greek public-sector institutions was normalized as a daily activity - but it was not considered 
the right thing to do by many in the organization, however. Our informants both accepted that corruption was part of their daily life, yet also deemed it should be eradicated. Second, we found that tolerance of corrupt activities played an important role in its normalization. On a secondary level, many informants tolerated corruption in there organization's as a fundamental part of everyday life, even though they labelled the misdeeds illegitimate. This suggests a hitherto unexplored mechanism that normalizes organizational corruption even when many stakeholders, including senior managers, disapprove of its existence. We call this a secondorder level of normalization, which mainly involves non-corrupt onlookers.

The paper is structured as follows. First, we provide an overview of the literature on corruption and its normalization, before positing our research question. Next, we explain our case study methodology, including data collection method and analysis. Our findings of corruption in the Greek public sector are then presented, allowing us to propose the concept of second-order normalization. Finally, we discuss the theoretical and managerial implications of these findings.

\section{Normalized Corruption}

As mentioned earlier, Ashforth and Anand (2003: 2) define corruption as the "misuse of authority for personal, sub-unit or organizational gain," where the term 'misuse' can mean illegal, unethical or illegitimate conduct. Conceptualizing corruption as illegal behavior might seem more straightforward given how the laws of a country delimit what is and is not corruption, and accordingly the most well-known types of corrupt activities, such as bribery, fraud or embezzlement, are illegal, in most countries. However, it is possible for corrupt actions to be legal but contrary to accepted social norms (Kish-Gephart, Harrison, \& Treviño, 2010), or for illegal actions not to be considered illegitimate or unethical in a given social context (Greve, Palmer, \& Pozner, 2010; Martin, Lopez, Roscigno, \& Hodson, 2013). In this paper, 
following Palmer (2008), we use a broader interpretation of the notion of corruption to include actions that are considered to be illegal, unethical, or socially irresponsible by our informants (Greve et al., 2010).

\section{The Normalization of Corruption Approach}

Research and many high-profile corruption cases indicate that despite its illegality and/or illegitimacy, corruption in organizations often persists for long periods of time. In the wellknown cases of Enron, Arthur Andersen and WorldCom, the corruption for which these companies and their executives were convicted endured for years before it was exposed (Elkind \& McLean, 2004; Toffler \& Reingold, 2004). This persistence of corruption is even more unusual given that most individuals involved were not stereotypical criminals but otherwise upstanding members of the community (Anand, Ashforth, \& Joshi, 2004; Ashforth \& Anand, 2003; Fleming \& Zyglidopoulos, 2009). Ashforth and Anand's (2003) concept of normalization provides a framework for explaining this persistence, describing how corruption comes to be seen as the 'way we do business here'. Normalization refers to how corruption is "embedded in the organization such that it is more or less taken for granted and perpetuated" (2003: 1). Ashforth and Anand (2003) identify three pillars that underscore the normalization of corruption: institutionalization, rationalization and socialization.

First, through institutionalization (Oliver, 1991), corrupt practices become routinized and embedded within the organizational structure so that they are enacted without any conscious thought regarding their appropriateness. Ashforth and Anand (2003) identify three phases: (1) the initial corrupt decision or act, (2) the embedding of the corrupt act in the structures and processes of the organization, and (3) the routinizing of corruption.

This institutionalization is similar to what Suchman (1995) terms 'taken-for-granted legitimacy', where an action, value or process is followed because the possibility for an 
alternative is not even considered by the individuals. Or, as Palazzo, Krings, and Hoffrage (2012: 323) say "people might behave unethically without being aware of it."

No matter how routine or legitimate corruption becomes in an organization, individuals often sense its intrinsic inappropriateness. This is where the second pillar of normalization comes in, rationalization. Various psychological justifications help participants to simultaneously enact corruption and absolve themselves of guilt. Rationalization is "the process by which individuals who engage in corrupt acts use socially constructed accounts to legitimate the acts in their own eyes" (Ashforth \& Anand, 2003: 3). Combining insights from moral disengagement theory (Bandura, 1999; Bandura, Barbaranelli, Caprara, \& Pastorelli, 1996), ethical fading (Tenbrunsel \& Messick, 2004) and neutralization theory (Sykes and Matza (1957), Ashforth and Anand (2003: 10) employ rationalization to explain how and why "corrupt individuals tend not to view themselves as corrupt." They identify a number of rationalizations that individuals may use prospectively or retrospectively: denial of responsibility ('I had no choice'), denial of injury ('no one was harmed'), denial of victim ('they deserved it'), social weighting ('others are much worse than me'), appeal to higher loyalties ('it saved the firm') and metaphor of the ledger ('I was just getting even').

The third pillar of normalization is socialization, whereby "newcomers are taught to perform and accept the corrupt practices" (Ashforth \& Anand, 2003: 25). Here they propose the notion of a "social cocoon" (Ashforth \& Anand, 2003: 26, also see Greil \& Rudy, 1984) to describe how newcomers are socialized into an otherwise covert system of misconduct. This social cocoon separates and conceals the wrongdoing from the outside world, be that other parts of the organization or the broader environment. This prevents the cocoon's rationalizations being subject to a reality-check through public exposure. As a result, newcomers come to accept and engage in behaviors they would otherwise have found objectionable. 
In short, the normalization of corruption in organizations can be described as follows. Individuals and/or groups engage in corrupt activities, but typically do so in a concealed manner. This is then perpetuated through processes of normalization by the perpetrators themselves, involving institutionalization, rationalization and the socialization of newcomers. As a result, the 'social cocoon' or 'microcosm' of corruption may spread or escalate in the organization, sometimes called a 'slippery slope' or 'snowballing effect', as evidenced in other research (Fleming \& Zyglidopoulos, 2009; Palazzo et al., 2012).

\section{Problem Areas}

We identify three problem areas. First, the theory was developed by drawing evidence from large US corporations in the private and non-state-owned sector. The same processes might not occur in different types of organizations such as in the public-sector, which do not have to operate under market discipline, are often used for political purposes and are generally exposed to the public eye.

Second, normalization theory assumes corruption occurs in a secretive sub-group of employees that hide it from the outside world, either within the organization or beyond. The role of non-corrupt bystanders and onlookers, which we believe are important for understanding how wrongdoing persists, is omitted. Does this non-participant audience facilitate or contribute to organizational corruption in any form? Yes, we will soon argue.

Third, attached to this assumption is the unstated expectation that when the corruption is publicly revealed, and the 'social cocoon' or 'parallel universe' (Zimbardo, 2011) is exposed to a non-corrupt audience, the wrongdoing inevitably stops. This has been confirmed in a number of high-profile corruption cases (i.e. Enron, Siemens and so on). In the Enron case, the corruption ended because the firm went bankrupt after extensive litigation (McLean \& Elkind, 2004); whereas in the Siemens case, the corporation was forced to pay billions in fines and 
undergo a major restructure of its compliance division to ensure that such behavior did not occur again (Telloglou, 2009). However, in the case of some public-sector organizations, the on-going corruption is common public knowledge and this does not halt it, on the contrary. In light of these problem areas of normalization theory, we investigated the case of corruption in the Greek public-sector, a setting that we believe will help us extent the insights of normalization theory in significant ways.

\section{Methods}

Research Setting: Corruption within the Greek Public-sector

In order to address the above-mentioned problem areas of the normalization thesis and extend its explanatory power, we investigated the Greek public-sector, where corruption is common knowledge. We conducted 58 semi-structured interviews with public- and private-sector managers between 2012-2019. Our rationale for this focus is as follows. First, by investigating the Greek public-sector, we are able to explore wide-spread corruption within a non-US corporate setting. Second, by interviewing a significant number of both public (and privatesector managers contracted to public organizations), we can explore the role of those who do not engage in the corruption, yet are nevertheless part of the social system of normalization. Third, given that the Greek public is well aware of the corruption within its public-sector organizations (Athanasouli, Goujard, \& Sklias, 2012; Koutsoukis, 2003; Lyberaki \& Paraskevopoulos, 2002; Katsios, 2015), this case provides a situation in which no 'social cocoon' is obvious, yet corruption is still somehow normalized, particularly among bystanders.

Corruption in Greece has been common for the last 40 years according to several studies (Pavlopoulos, 1987; Manesiotis 1991; Kanellopoulos et al., 1995; Tatsos 2001; Kollintzas 2000). Since 1974 there has been a constant rise of the underground economy, with a GDP loss about 1 trillion drachmas in 1984 (Pavlopoulos, 1987) and in 1991 tax evasion being 
responsible for nearly half of the public-sector deficit (Manesiotis 1991). TI has consistently ranked Greece as one of most corrupt EU countries over the last twenty years. Similarly, a major European Commission (2014: 16) study found that in Greece (along with Croatia, the Czech Republic and Lithuania), "between $6 \%$ and $29 \%$ of respondents indicated that they were asked or expected to pay a bribe in the past 12 months, while $84 \%$ up to $99 \%$ think that corruption is widespread." Of interest to us given our focus on the public-sector, $93 \%$ of Greek respondents agreed "that bribery and the use of connections is often the easiest way of obtaining certain public services in their country" (European Commission, 2014: 7).

As mentioned earlier, corruption in Greece also has the interesting characteristic of combining elements of developed and developing countries. Given its geopolitical location, Greece exists at the crossroads of three cultural spheres of influence: Europe, the Balkans and the Middle East. Europe is "a region that prides itself" on having "some of the most robust integrity systems in the world" (TI, 2018), whereas both the Balkans and the Middle East are considered to have relatively corrupt public-sector bureaucracies (Anastasakis, 2005). Therefore, the Greek public-sector finds itself operating at a corruption level not dissimilar to that of its developing neighbors (Anastasakis, Bechev, \& Vrousalis, 2009), while simultaneously aspiring to achieve European levels of integrity.

It is thus uniquely suited for our research question, on why corruption persists, even if its existence is well-known. According to Kollintzas (2000) corruption in the public-sector could be facilitated either because of lack of control and monitoring of civil servants or because illegal actions go unpunished due to the existence of corruption within the legal system. The former is more prevalent in Western countries, while the latter is more prevalent in developing countries (Kollintzas, 2000; Blundo et al., 2013). In Greece, the two types occur at about the same frequency, with many cases of falsification of court decisions (Kollintzas, 2000). Thus 
Greece provides an attractive case that enables us to shed light on unexplored insights about the determinants of the persistence of corruption.

Given that our initial data collection time period (2012-2014), it could be argued that the Greek financial crisis might have influenced our findings. However, we do not believ this is the case. Having consulted studies of corruption that predate the crisis (Pavlopoulos, 1987; Manesiotis, 1991; Kanellopoulos et al., 1995; Tatsos 2001; Kollintzas 2000), examining 1898 self-reported incidents of corruption between 2000-2016 (at the http://www.edosafakelaki.org/, and additionally interviewing (in 2019) older generation Greek managers, who have witnessed much corruption in their long careers, we concluded that the way corruption functions in Greece does not seem to have been changed by the financial crisis.

\section{Methodology and Data Collection}

We chose a qualitative methodology consisting of semi-structured interviews because this allows us to capture ambiguous, personal and ambivalent data and follow-up with questions about significant themes. A one-on-one interview in which a relationship of trust was built seemed more amenable to yielding the data that interested us compared to administering impersonal surveys. Our informants were mid to late-career managers, employed in a publicsector organization, or equivalent managers, who worked in private sector businesses, but dealt extensively with public-sector organizations (e.g., subcontractors). Informants attended evening executive education classes in a major Greek business school.

Although there are weaknesses associated with using students or 'convenience samples' in organizational research (see Peterson \& Merunka, 2014), unlike undergraduates, these attendees studied part-time and were employed at the time of this research, providing an unusual opportunity to explore corruption in the public-sector. On average, the interviews lasted about sixty minutes, were recorded, transcribed, and translated from Greek into English 
by two of the authors, who tested each other's translations. The interviews were mostly conducted by one of the authors, but in some cases two authors were present.

We invited 180 people to participate in the study on the condition that they had observed public-sector corruption in their line of work. Fifty-eight responded positively and were interviewed, between 2012-2014 and then again in 2019. Roughly half came from state organizations, whereas the other half came from private sector organizations. We included private sector informants because the governmental sector is integrated with private organizations, and in many cases difficult to disentangle. If we omitted private sector employees, we would risk excluding an important source of data. All informants were experienced employees in positions of responsibility (with an average working experience of 13 years). Tables 1 and 2, in the Appendix, provide a list of the informants, their position and affiliation in anonymized terms.

\section{Data Analysis}

Our study consisted of four phases. Before collecting interview data, we conducted an extensive background investigation of archival sources (websites, newspaper articles, books). This included examining a Greek website that encourages individuals to report anonymously on incidents of corruption they have witnessed or been involved in (http://www.edosafakelaki.org/). We went over the 1898 incidents of corruption reported by the general public between the years 2000-2016 on this website. Moreover, we consulted several reports on corruption in the Greek public-sector (Pavlopoulos, 1987; Manesiotis 1991; Kanellopoulos et al., 1995; Tatsos 2001; Kollintzas 2000). We established that corruption in the Greek public-sector was openly acknowledged by a wide range of stakeholders. Contrary to what we would expect in typical corrupt settings, where a degree of secrecy and concealment 
is involved, corruption in the Greek public service was described as an 'open secret'. Everybody knew about it, but this did not appear to impede its persistence.

Given existing theories of organizational corruption and its apparent 'normality' in the Greek public-sector, the second phase of data collection focused on its normalization and rationalization. In semi-structured interviews, we asked 33 informants about their experiences with corrupt activities in their workplaces, focusing on normalization.

The interview schedule consisted of three key sections that concentrated on a) the corrupt activity, b) aspects of normalization and c) possible antecedents. We asked informants if they had observed corruption in their immediate team and/or department, leaving their own participation unprompted in the questions. We left it to the informant's discretion as to whether they spoke about their own corrupt practices and most stated they were bystanders to the wrongdoing. Of course, they might have simply been hiding their own involvement. But given the 'open secret' of the 'irregularities', some informants were untroubled by admitting to their complicity. The majority of self-proclaimed non-participants conveyed a deep disdain for corruption, which tended to imply truthfulness regarding their own behavior. Regardless of veracity, the accusatory 'othering' of perpetrators as an offensive minority, our interviews provide compelling insights into the discursive landscape of corruption as an 'open system', especially the part played by those who felt non-complicit in the wrongdoing.

We began by examining the data from these 33 informants, using qualitative data analysis from a grounded approach (Charmaz, 2008). The data were initially coded through an open coding process (using first-order categories) where the coding units were sentences or paragraphs. Then through axial coding (Strauss \& Corbin, 1990), we collapsed our first-order concepts into second-order themes. We found that themes we had not originally anticipated emerged during this analysis, so another 20 interviews were conducted (our third phase of data collection). For instance, normalization was often framed in an ambivalent manner in the 
second-phase interview-data, sometimes present and sometimes not, and importantly 'tolerance' emerged as a key concept. Here we define tolerance as follows: to allow the existence, occurrence, or practice of something that one dislikes or disagrees with, without interfering.

The 'open secret' motif also recurred during the interviews, confirming our hypothesis that corruption in the Greek public-sector persisted despite it being both a) openly known to exist and b) considered illegitimate. This data did not fit existing models regarding the normalization of corruption, which implied secrecy and assumed that a sudden 'revelation' would hasten its end (arrests, scandal, etc.). During our third phase of data collection, we asked additional follow up questions concerning these more ambiguous issues.

In our final recoding of all 53 interviews (see Table 1, Appendix), we first coded for the normalization of corruption, using codes from Ashforth and Anand (2003): (1) the corrupt act, (2) motivation for the corrupt act, (3) normalization of corruption: (3.a) institutionalization, (3.b) routinizing, (3.c) socialization and (3.d) rationalization. Then we coded the existence of (4) tolerance with quotes that expressed (4.a) resignation, (4.b) apathy, (4.c) powerlessness and (4.d) cultural inertia. We then were able to home-in on the normalization of tolerance by non-participating stakeholders or what we refer to as second-order normalization.

Finally, after analyzing our data and positing our conclusions and theoretical implications, we interviewed five further senior individuals within the Greek public and private sector, who have long experience with corruption, in order to conduct a robustness check of our findings (see Table 2, Appendix). In short, we asked them about their understanding of the nature of corruption in the Greek public-sector and then presented them with our findings. In both cases, their responses reconfirmed our central conclusions. 


\section{Findings: Corruption in Greek Public-sector Organizations}

Before discussing data regarding tolerance, we summarize two preliminary findings.

Firstly, we found that in contrast to the relevant literature and despite of observing it daily, nearly all informants stated that corruption is wrong and/or illegal. Most of our informants reported that they regularly observed corrupt acts, which they referred to as irregularities or illegalities, while dealing with public-sector organizations. Four types of corruption were prominent: bribery, fraud, falsification of records or documents (for a fee) and favoritism in tendering processes. For example, a public-sector employee might accept a 'speed up' bribe of $€ 100$ to help an application be processed quicker. We were also told of a private manager who misappropriated $€ 100,000$ in EU funding and an informant described a case where a state department employee falsified an applicant's exam result (for a fee) when issuing an aviation license. The allocation of public-sector contracts to 'friends' in the private sector was frequently mentioned.

A significant number of informants stated that corruption was motivated by publicsector employees believing that they were underpaid and the complexity of the regulatory framework, which made the completion of normal procedures time consuming and uncertain:

A bribe is offered to make sure the job gets done because it's very difficult to get your job done if you don't give some money. (Pb-1)

As expected from the relevant literature (Anand et al., 2004; Ashforth \& Anand, 2003), informants also touched upon the theme of normalization while explaining how and why perpetrators are able to habitually engage in wrongdoing. Rationalizations like 'everybody does it', 'nobody got hurt', 'doing this for a higher purpose' were attributed by our informants to those engaging in corrupt deeds. Moreover, in accordance with the idea of incrementalism, 
sometimes referred to as 'a slippery slope', informants mentioned cases where minor transgressions slowly accumulated into greater ones.

When you are first employed you have a sense of duty. But sometimes things happen. It's noticed but nobody bothers you and you make a small transgression, it's very easy to move from this to a bigger one. And there were no punishment procedures. $(\mathrm{Pb}-13)$

We also found evidence where newcomers were socialized into the 'way things are done', something which perpetuates corruption within particular groups, as described by Ashforth \& Anand (2003).

Secondly, some data deviated from the typical normalization thesis in important ways, especially pertaining to the previously unexplored role of non-participants. Most significantly, corruption did not take place in complete secrecy but was intended called an open or public secret in which most members of the organization (and sometimes clients, the general public, etc.) knew about it. Moreover, despite the rationalizations mentioned above, non-participants (including those with the power to make a difference) continued to define these deeds as corruption (as opposed to some post-rationalized euphemism). There was little 'ethical blindness' (Palazzo et al. 2012) or 'ethical fading' (Tenbrunsel \& Messick, 2004) among this group. Here are some indicative examples:

Irregularity, in the sense of corruption, I see all the time around me when cooperating with the public-sector. Many times I have myself been forced to participate in such a procedure, in order to either acquire an agreement or proceed with an agreement or in order to achieve some self-evident things. (Pr-13) 
I do not think corruption is considered normal in the organization I work for. I believe that everyone knows the ethical limits. $(\mathrm{Pb}-27)$

I think this is a common secret. Corruption or irregularities in the public-sector is not something new. $(\mathrm{Pb}-28)$

Yet the corruption persisted regardless, which represents a puzzle. Interviewees referring to the pervasiveness of corruption as an 'open secret'. By this they meant a commonly accepted fact that is not officially broadcasted, but neither requiring constant concealment. For example, a manager for an advertising company spoke about bribery in obtaining public-sector contracts:

Usually, these incidents are quite frequent and in many tenders, it is a common secret, more or less everybody knows who will win the bid... So, there is a common acceptance from all that this happens, but we pretend we do not see it. (Pr-6)

Other views on this theme include:

... it's [corruption] a common secret, it's just the way things happen around here. $(\mathrm{Pb}-$ 1)

It's an open secret, so common that.... (Pr-12)

Thus, returning to our question. How can corruption be sustained in an 'open' organizational environment in which it is a) defined as corruption by most organizational members, b) considered detrimental to the organization by nearly everyone and c) the majority of 
organizational members are non-participants? In other words, as per current theories of normalization, why does a scandal not ensue and the corruption end?

\section{Tolerance Towards Corruption}

We were surprised by how most informants tolerated the corruption they witnessed. Only two (from our initial 53 informants) said they reported it to their superiors. The remainder stayed silent (and not because they were perpetrators). We asked why and found that tolerance itself (instead of the corrupt deed) was considered normal for a whole range of reasons, some real and some imagined, even by senior managers who had the power to make a difference. We identified a number of second order themes that can be aggregated into agent-focused tolerance and structure-focused tolerance of corruption. Agent-focused tolerance takes place at the individual level and is driven by two major second-order themes: resignation towards the activities of wrongdoers and apathy about whether one should do anything if corruption is witnessed. Structure-focused tolerance is characterized by beliefs about the perceived structural inadequacies of the environment - the second order themes here are the assumption that the organizational system is powerless to address and sanction wrongdoing and is sustained by cultural inertia, in which Greek people are thought resistant to change. We discuss these findings following, as depicted in Figure One inspired by the Gioia method (see Gioia et al., 2013).

Insert Figure One here

Agent-focused Tolerance 
Resignation. According to our data, resignation is a common theme that underlies tolerance. In this context, acceptance is the process of considering corruption as a simply and unchangeable fact of life. This is not the same as consent or condoning the wrongdoing, however. Observers perceive corruption to be illegitimate but are fatalistic regarding the effectiveness of intervening. Such resignation might be driven by their fear of being victimized if they make a complaint, and especially if this is accompanied by the collusion of top managers (Jávor \& Jancsics, 2016) and political interference (Collins, 2009). Many of informants appeared to have adjusted to a work environment that views such wrongdoing as inevitable. For example, some said that one must tolerate corruption because it is fundamental to how the 'system' works, whether one likes it or not. An employee in a property development firm that gives bribes to the public-sector explains his supervisor's demeanor, "whether he feels remorse or not, I think he accepts it as a necessary evil" (Pr-2).

One informant stated he had little choice but to accept that his company will use bribes to obtain important permits from a state agency. Otherwise his employer would be disadvantaged and lose crucial business contracts: "it is like we are all in the circle and you know if you do not play by their rules it will hurt you in the end" (Pr-13). Others felt that turning a blind eye was the best way to avoid being implicated in the wrongdoing, as a Ministry of Defense employee remarks:

Even if you see something happening, you do not want to get involved with the procedure, which could even lead you to criminal consequences, nobody wants to get involved. $(\mathrm{Pb}-8)$

Self-protection was also mentioned: 
The most important element that prevents the situation from being fixed is all of us. All of the workers are trying to protect their individual interests: the junior ones trying to protect their small salary, the more senior ones trying to protect their positions and their salaries, their big salaries, all of these are defending the maintenance of the situation. $(\mathrm{Pb}-4)$

Another resignation factor is managerial authority and the consequent fear of punishment. If superiors are perceived to be corrupt, then speaking out could be very damaging to your career: "they support the guilty and the innocent ones they shoot" (Pb-17). Some informants even absolved their superiors, since they too could lose their jobs. As a municipality worker observed regarding corrupt mayors,

All the supervisors in all the municipalities have been appointed directly by the mayor, if the supervisor goes even a little against the mayor...he is putting his position in danger, because the mayor can replace him immediately. (Pb-11)

The fate of those who do speak out about corruption becomes a stark warning about why one must tolerate it:

A colleague had serious objections [concerning the falsification of seminar attendances among co-workers]. The only thing that he achieved was to get the whole organization against him, which had a very big psychological cost for himself without bringing any result. $(\mathrm{Pb}-9)$ 
Combined with the managers' concealment, such an environment has an important effect on non-participants and their tolerance (of corruption) levels. As an employment agency manager states:

After my report about the incident, even my manager that was called by the district attorney to make a testimony, when she was asked about the falsification of the documents, she answered that there was no falsification. (Pb-17)

As another state worker argues, silence becomes the only sensible option:

They [perpetrators] don't feel the need to explain [the bribe] because they know the work will be done without any consequences and I can get away with the protection of my supervisor. Nobody will say anything so why not do it like this? $(\mathrm{Pb}-10)$

Apathy. A number of informants appeared apathetic about the corruption they witnessed. Apathy is a similar to indifference but associated with lack of motivation. One might be outraged by the wrongdoing but overcome with a sense of futility in light of the impunity with which corrupt individuals behave. For example, the following informant contends that the courts would not protect a 'whistleblower':

What mainly prevents corruption from being corrected is that you will not find justice, I mean, you say OK, I will do the right thing and I will report this, I will not give in to whatever extortion, and then who will stand by me? I don't think there is any solution to this so far. (Pr-2) 
In some cases, informants' apathy was indicated by loss of meaning, isolation and the feeling that they were in ethically barren workplaces (Karakas and Sarigollu, 2012):

An inspirational figure is lacking, someone who would give vision for the Bank because in the older days all the employees where very dedicated to the organization and even now there are some that continue to see things that way. But now seeing all these changes, irregularities, restructurings there is a disappointment, so another obstacle is this disappointment this sense of no justice $(\mathrm{Pb}-4)$

There is no use. Even if the disciplinary council decides to sentence one and decides to impose a particular sanction, when this penalty goes further up to be confirmed by senior management, maybe some general secretary or minister or some other, will nullify it or erase it or just place it in the archive and never carry it out. (Pb-5)

Even if apathy was not expressed accurately by the informants, it was obvious that the nonpunishment of corruption created a loss of interest:

They were called by the disciplinary committee and they did explain themselves and I think nobody was punished in the end $(\mathrm{Pb}-12)$

He wasn't fired he was fined a particular fine and he was transferred to another division so that he doesn't have any contact with people. $(\mathrm{Pb}-6)$

It is interesting to note that these descriptions of non-punishment are not only derived from direct experience, but also 'rumor' and 'beliefs' about how informants think the organization 
functions. Corruption taking place for decades in the Greek public-sector makes this finding not surprising, though, as rumors become beliefs when they are heard repeatedly and fit with an already existing situation (DiFonzo and Bordia, 2007, Einweiller and Kamins, 2008). Organizational rumors are considered to impact the employees' attitude and behavior, leading them, for example, to 'lowered morale' and mistrust. For example:

There was a rumor about 2-3 other colleagues that there were similar incidents [not making appropriate samplings], but except from removing them from that division that had to do with collecting fees, nothing else happened ... I think that nobody was punished in the end. $(\mathrm{Pb}-12)$

\section{Structure-focused Tolerance}

Powerlessness. The observed or expected absence of punishment concerning corrupt employees seemed to fuel tolerance. According to our findings, this non-punishment may be attributed not only to deliberate concealment of corrupt incidents, but also to the structural powerlessness of the system to respond effectively because of ineffective compliance measures and/or inadequate controls. Why bother reporting corruption if the legal system cannot punish the perpetrators?

Our data suggests that organizational powerlessness is perceived to exist at both the top management level and societal level (law courts and regulators). For example, the inability of the court system to impose penalties and its arcane complexity - permitting plenty of 'holes of the system' - appears tolerant of corruption itself, but also creates preconceptions about corruption in broader Greek society: 
I think the most important element that prevents this situation to be fixed is the lack of disciplinary procedures. In the Greek public-sector that I know at least, the problem is that there is a very complicated procedure. ...once [the wrongdoer] is referred to a disciplinary council, this council is made up of union members who could make the penalty into a very lenient one, or even erase it. $(\mathrm{Pb}-5)$

The inability of senior management to monitor employees and update organizational compliance procedures creates opportunities for illegalities, and thus gives the impression that organizations are unable to cope:

The system was not ready to manage the money that it was given. The decision-making systems were not very sophisticated. $(\mathrm{Pb}-1)$

During the last stage of an EU project, the project managers started wasting the budget to expensive suppliers, because they had to deliver a report demonstrating the absorption of the funding by the end of the year. If they had not wasted money, the department would have not been funded again. This kind of illegality was in a sense "allowed" by the organization's incapacity to manage this project. ( $\mathrm{Pb}-12)$.

A frequent and important observation by many interviewees has been the inefficient exploitation of digital technologies in the public-sector. As many informants argued, such an automatization and digitization in the public-sector would minimize corrupt practices (Greve, 2015). Although actions have been taken towards the digital transformation of the Greek public-sector, these actions were deemed insufficient. According to our informants, the efforts to use digitalization as a tool to minimize corruption have been hindered by gaps in the 
appropriate skills of various managers as well as the choice of often unsuitable digital applications for different tasks:

Since there is no control, the supervisors are in no position to manage, they do not have any managerial abilities, if the supervisors do not know how to use the computerized system, how are they going to control and follow [keep track of] something. ( $\mathrm{Pb}-3)$

There are computerized systems, but the software used does not allow the connectivity between the departments. Maybe it is not the appropriate one. Sometimes the software the municipalities buy, because they choose specific companies that sell software for municipalities, do not cover their needs regarding financial management. $(\mathrm{Pb}-11)$

Nothing happens through computers everything is done manually. There is however a computerized system but nobody ever checks $[\ldots](\mathrm{Pb}-2)$

Despite the prevalent ineffectiveness of digitalized reforms, some interviewees noted that the use of information systems did somewhat limit corruption:

There were many corrupt incidents because there was no real crosschecking of information. Since the new computerized system has been in power since last year there are many such incidents that have been discovered. $(\mathrm{Pb}-3)$

We solved this problem by getting the computer system to manage the procedure. [...] The digitalization is the cornerstone in the prevention of corrupt behaviors ... (Pb-6) 
Deliberately or not, the system's inability to deliver justice or to effectively supervise an organization's workforce often makes tolerance an inevitable response among the nonparticipating observers of corruption.

Cultural Inertia. Inertia refers to the belief that Greek culture is resistant to change (Kuppens, Allen \& Sheeber, 2010) and will not easily reform. Corruption has been embedded in the Greek public-sector for decades and so tolerance stems from the sense that nothing will change (Kollintzas, 2000). Thus, according to our respondents, a radical mentality shift is required.

This aspect of tolerance functions like a rationalization: everybody is doing it so why bother doing things differently. We note the sentiment in both the self-descriptions of informants and their explanations of others. Some informants said that 'speaking up' about the corruption was difficult because of the prevailing 'why bother' attitude among co-workers. For example:

The attitude that everybody has is why should I change? This attitude, the "why bother attitude' ... I won't bring about change, since everybody works like this, the whole system works like this from primary school up, I don't know, why should we change?' $(\operatorname{Pr}-8)$

Thus, inertia is (perceived to be) a result of cultural traits that prevail among employees. It seems that there is an intense peer influence, a 'herding' phenomenon, even for newcomers that soon come to accept their older colleagues' mentality.

There is the old type of employees, who have grown up with corruption. People 45year-old and older. And this is something they do not control. It is in their culture. $(\mathrm{Pb}-$ 2) 
Others mention a code of silence that no one is willing to "break", especially when nonparticipants enter an already corrupt environment:

In the Greek public-sector such situations are covered up daily... There is an omerta kind of rule, a rule of silence we do not talk too much about it because we all believe that it is obvious and it should be done and it is done. People do not prevent you, but at the same time they do not try to erase this phenomenon they just keep quiet about. $(\mathrm{Pb}-$ 5)

Except from this passive participation in an "omerta kind of rule," it seems that the code of silence among colleagues is also re-enforced by the lack of whistleblowing policies and systems. According to Zhuang et al. (2005), culture affects whistleblowing. There have been several cases of public employees not being protected under the law or even get disciplined for blowing the whistle (Peeples et al., 2009). Therefore, in addition to the structural tolerance of the system towards corruption, the lack of whistleblowing policies and systems has an additional negative impact to the perpetuation of corruption:

I made a written and verbal complaint against these colleagues and- of course- there were lawsuits for compensation and lawsuits from them. Nobody came to the court (to support me), no lawyer, no manager thought of giving me legal coverage. [...] $(\mathrm{Pb}-17)$

Nobody from the organization was willing to make a report. But it was very important for me, so I went to a lawyer and he told me that from the moment that nobody else is willing to make report I cannot make one because nothing will result from it. $(\mathrm{Pb}-3)$ 
Inertia is also driven by the belief that doing things in a less corrupt manner would create more work for everyone:

The daily routine, everybody has learned to work in a particular way and they are trying to minimize their work and of course this means that they do not like changes that could make them think more, change their way of work, work more or have more responsibility, nobody wants this $(\mathrm{Pb}-5)$

The most important thing that prohibits correction of such phenomena I think is an overall indolence and an overall will to let things get mixed up, so that some unofficial payments may be justified, and so that one is forced to bribe. This is the major reason for not changing things as well as the unwillingness of some to comply with change. (Pr-14).

\section{Findings from additional interviews}

The insights of five senior older Greek public and private-sector managers, specialized in corruption issues assured us that, first, corruption has been an 'open secret' for several decades, and second, that the way corruption functions in Greece was not demonstrably influenced by the financial crisis. There were some interesting suggestions in these views. For example, an informant that had been dealing with the issue of tax evasion during his 30 year career in the Bank of Greece (Rc-2) highlighted that according to a quantitative study he wrote a few decades ago, tax evasion was the most widespread and tolerated behavior, being an obvious proof of the inefficiency of the tax authorities. He added that the economic crisis might have set some primary limits to corruption, but corruption cannot be reversed radically because of its embeddedness in the operation of the Greek public-sector (i.e., inertia). 
According to an Inspector-Auditor of Public Administration who investigates corruption (Rc-1), an economic crisis is a short-term (or at most medium-term) problem, while corruption in public administration is a long-term one. Reducing corruption requires long-term efforts, because it is a complex political and social phenomenon. Even if there is a correlation between the economic crisis and corruption it needs a long time for positive benefits to reflect in the society which in the case of Greece haven't emerged yet even at the end of the economic crisis. Further, according to a Senior Executive of the Anti-Money Laundering Authority (Rc3 ) in times of an economic crisis, the government makes "grand declarations" on measures about anything that might boost the society's morale, including corruption, but they are usually plans, policies and protocols for treating the symptoms and not the disease.

\section{Second-Order Normalization of Corruption Theory}

To help explain how this tolerance among non-participant observers can function within corrupt settings, we propose to extend the theory of the normalization, which we call "secondorder normalization". On one hand, the normalization of corruption evolves pretty much as Ashforth and Anand describe (see Figure Two), a process that we refer to as "first-order normalization." On the other hand, we propose, tolerance, both types of tolerance, co-evolves and becomes normalized along-side corruption (see Figure Three), a process that we refer to as second-order normalization. In a sense both orders of normalizations answer the question of why corruption persist in organizations. However, the second order normalization approach expands the normalization of corruption theory by providing a possible answer to the question why corruption persists even when it becomes public knowledge. Of course, we do not have process/temporal data to observe how this second-order normalization might develop over time, as the picture of corruption we found in the Greek public-sector has remained practically unchanged for decades. However, findings suggest that tolerance co-evolves with corruption 
and that it might even follow a similar normalization trajectory. Let's look at both in more detail.

\section{First-Order Normalization}

In Figure Two (first-order normalization of corruption) we capture the evolution of wrongdoing within organizations, as theorized by normalization theory discussed earlier. If the corruption is not exposed to significant non-participant stakeholders (other organizational members, competitors, the general public, law enforcement, government regulators, etc.) then it continues to persist until it becomes unsustainable. If it is exposed, however, then the organization enters into a legitimacy crisis, prompting reform or its untimely demise.

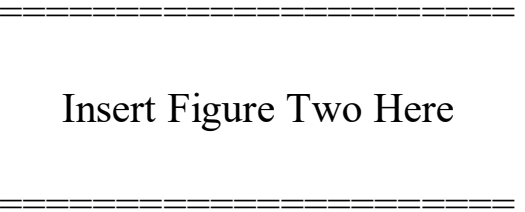

\section{Second-Order Normalization}

However, in Greek public-sector organizations we studied, corruption persists even though its existence is common knowledge, a situation where non-participants organizational members and the public at large are very aware of its existence. What are the mechanisms that allow this to occur?

We propose that tolerance co-evolves along with corruption and forms a positive feedback loop, which we refer to as second-order normalization. This plays a paramount role in explaining the persistence of corruption, even though it is an 'open secret'. In a sense this second-order normalization does not pertain to the corrupt deed itself but its actual and projected (or imagined) tolerance among a wider audience. Echoing Palmer's (2013) 
arguments, second-order normalization perpetuates corruption, we argue, because certain first order factors (see Figure One) fuel a). a feeling of resignation and apathy and b). a perception of organizational powerlessness and cultural inertia. Figure Three depicts the proposed process that underscores second-order normalization.

Insert Figure Three Here

The data leads us to surmise that tolerance can become the domain of a secondary set of normalizations among non-participants. Our informants describe a situation in which they (and their colleagues) unambiguously disparage bribery, the falsification of records and so forth, but feel that there is no point in doing anything about it for one reason or another. Secondorder normalization can thus be seen as a process where it is not just the corrupt act that is justified (by a minority of perpetrators) but also, once revealed, its toleration by a nonparticipating majority. In relation to this facet of the data, normalization of tolerance is most likely operating at three interconnected levels of analysis: the individual, organization and society.

At the individual level, we can say that the concept of second-order normalization (of tolerance) allows us to explain how tolerance becomes normalized within members of the various organizations involved. In the organizations described above, the non-tolerance of corruption is considered unusual, abnormal and dangerous, not the other way around, as we would assume. Put differently, getting away with bribery and the falsification of records was believed normal by many of the participants rather than out of the ordinary. Even if informants had the organizational authority to intervene, most did not think it was worthwhile for a number 
of reasons. Those who do speak out and take a stand are victimized by senior management. Perpetrators go unpenalized. As one informant remarked, "nobody will say anything (about the wrongdoing), so why not do it like this?" (Pb-10).

At the organizational level, we can say that exposure and common knowledge in this relatively 'open system' generally does not lead to official censure because stakeholders have become so used to it that they appear unmoved in its presence, even as non-participants. Moreover, individuals who are identified as corrupt are either not investigated or given soft reprimands, and sometimes, found innocent, even when their culpability is unquestionable. This non-punishment was explained by informants in a number of ways. Officials on disciplinary panels were corrupt themselves or had close ties with the accused. Supervisors who might challenge the wrongdoing would be removed by their superiors if they did. Thus, the tolerance becomes institutionalized within the organization.

At the societal level, tolerance is further normalized by informants apropos their preconceptions about corruption in broader Greek society, especially law officials. This encourages people to turn a blind eye, even when they decry the harm corruption inflicts. For example, the main reason why the broader public-sector is corrupt, according to a management consultant, is because it is supported by senior directors and political ministers (Collins, 2009). Extensive political interference in public-sector appointments was identified by many of our informants as a factor that contributed to the normalization of silence. Politicians or trade unions offer protection from prosecution to their appointees or members, as a way of 'protecting their own'. Even after a corrupt individual is sanctioned by a governmental disciplinary council, "some general secretary or minister or someone else will nullify it or erase it or just place it in the archive and never carry it out" $(\mathrm{Pb}-5)$. Adding to this the ineffectiveness of the court system, tolerance can be institutionalized at the societal level as well. 
In this paper, we have presented a 'snapshot' of a particular empirical situation. However, as with the temporal development of corruption more generally (see Brief, Buttram, and Dukerich, 2001; Fleming and Zyglidopoulos, 2009; Palazzo et al., 2012), we suggest that the normalization of tolerance could also evolve over time. Once this secondary normalization is established, an ethical inversion takes place. Whereas tolerance of individual and/or group wrongdoing would have once clashed with prevailing norms of acceptability, now it is intolerance that contravenes dominant organizational norms.

\section{Discussion and Conclusions}

We believe our findings make a number of contributions to existing literature, mainly by extending Ashforth and Anand's (2003) original framework by proposing the concept of second-order normalization. Our approach includes organizations in a non-US, public-sector setting, where corruption persists even when it is widely known, which in the US would probably cause a scandal. Moreover, we observed how corruption persists in an 'open system', in contrast to a 'social cocoon' as typically studied. This has permitted us to capture the importance of the tolerance among non-corrupt participants when it comes to perpetuating organizational wrongdoing. We have also identified two kinds of tolerance: agent-focused and structure-focused tolerance.

With respect to this tolerance (both agent and structure-focused), our informants exhibited what could be labelled as 'outrage fatigue' or 'learned helplessness.' Viewed through the rational-actor approach of corruption (maximizing gains and minimizing costs), identified by Jancsics (2014), the behavior of our non-participating but tolerating corruption agents makes sense. From a rational-actor perspective, they decide that tolerating corruption is in their best interest. Having repeatedly witnessed their colleagues, who spoke up against corruption, being socially penalized, ostracized and not supported by their managers, it seems that our non- 
participating individuals decide that speaking up would cost them too much, to no effect. Therefore, under the circumstances, tolerance was the most rational choice.

Our argument adds to the growing literature on the normality of corruption. As Palmer (2013: 5) argues regarding the extant research on this subject, corruption is not abnormal, rare, aberrant or perpetrated by 'bad' people. Instead it is

... a normal phenomenon; behaviour that is prevalent, not much different than rightdoing, perpetrated by people who are for the most part upstanding (otherwise ethical, socially responsible, and law abiding), and is a function of a plethora of structures, processes, and mechanisms that are integral to the efficient and effective functioning of organizations (Palmer, 2013: 5).

We think our paper adds three key insights to this observation. First, not only are corrupt actors engaged in normalization but witnessing non-participants too. Second, not only are corrupt deeds normalized but also the social reaction to them, in this case tolerance. And third, normalization does not need to take place in a secret 'social cocoon' in order to persist, as widely assumed. It can also occur in the open, making the wrongdoing even more insidious and difficult to challenge.

Our paper has several managerial and policy implications.

First, even though it might appear that this tolerance of corruption is a grave problem in the Greek public-sector, it could also be interpreted in a positive light. It is easier to eradicate or minimize corruption in a sector where individuals tolerate it but find it reprehensible. This means that any anti-corruption measure that policymakers might introduce would be welcomed by those who tolerate corruption without participating in it. 
And second, given that it is not the corruption that has being normalized, but its perceived tolerance, organizational managers who wish to minimize corruption should consider the perceptions among non-participants in the workplace rather than focus exclusively on the corrupt deeds themselves. Non-punishment, lax compliance and so-forth not only encourages bolder forms of corruption but apathy among peers, which too perpetuates wrongdoing.

The limitations of our study ought to be mentioned too since they may assist future research in this area. First, our data are not processual but present a structural 'snap-shot', with temporal evolution referred to by informants by not directly observed. In order to test our second-order theory of normalization, therefore, additional research might collect processual data, where the micro-mechanisms that normalize tolerance can be studied with respect to corrupt deeds and their first-order normalization. And second, future researchers could analyse tolerance among a wider range of stakeholders, including the EU, the Greek judiciary, various NGOs and so on. Given the interconnectedness of the global economic system, it is possible that global organizations like the EU or the World Bank and the IMF influence the decision making of nation-states and exert a certain level of influence towards processes and systems that reduce corruption. It would be, therefore, very relevant and interesting for future research to investigate the role that the EU or other international organizations have had or are having on the corruption and its tolerance in the Greek public-sector. From our preliminary understanding is that the EU played a significant role in creating an aspirational, non-corrupt ideal for the Greek public-sector, whereas it has not (yet?) been able to eradicate corruption and its tolerance.

One final limitation is important to discuss, namely generalizability. The Greek publicsector provides a useful 'extreme case' (Flyvbjerg, 2006), so how generalizable is our theoretical model beyond this specific context? (also Lincoln \& Guba, 1985). We doubt that 
the findings are limited to Greece alone, so variations and similarities in other countries and industries would deepen our understandings of how tolerance works in this respect. Indeed, we should resist the temptation to conclude that Greece is an outlier and thus not useful for understanding public sectors in less corrupt counties like the UK, Belgium and Sweden, etc. Corruption is, however, a global phenomenon. Although Greece is an extreme case, it may still help us see mechanism present in a less explicitly form elsewhere.

Our model of tolerance may have utility beyond Greece in other respects, including multinational organizations operating from relatively non-corrupt countries. For example, in the case of FIFA or Siemens, both operated from and were headquartered in non-corrupt countries (Switzerland and Germany, respectively), but in both cases, Switzerland and Germany tolerated and failed to intervene in the corruption that these corporations were engaged in abroad, thus making it possible for the wrongdoing to persist for many years.

Does our model have any relevance to private sector organizations? Perhaps, especially those that have a high profile in the public domain and control specific markets, especially prominent $\mathrm{B} 2 \mathrm{C}$ corporations. However, private corporations carry an important distinction: they must operate under a market discipline that does not allow them to remain legitimate if corruption is revealed to shareholders, consumers, government regulators and so-forth. Highly visible corruption in particular will inevitably force private corporations into a major legitimacy crisis and dire consequences will ensue. Whereas public sector organizations can suffer that legitimacy crisis and yet continue up to a point. Thus our model would tend to apply to public-sector organizations that have enough 'slack' to continue their operations even though their corrupt practices are highly visible.

To conclude, we hope that our research not only sheds light on a hitherto unexplored facet of corruption and its normalization, but also provide new conceptual tools for those who seek to eradicate it from our organizations. 
Figure One: Tolerance

\section{First Order Concepts}

Second Order Themes

Aggregate Dimensions

- Resignation and fatalism

- Fear of being victimized

- Concealment by managers

- Political interference

- Wrongdoing perceived as inevitable

- Lenient punishment

Injustice feelings
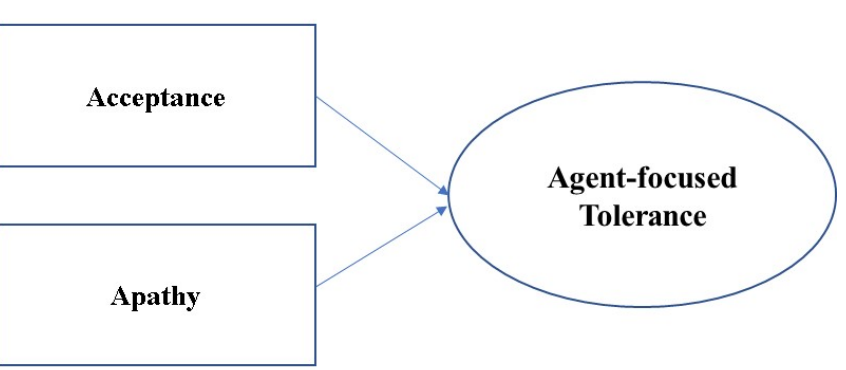

- Ineffective compliance measures

- Inadequate control mechanisms

Inefficient exploitation of digital technologies
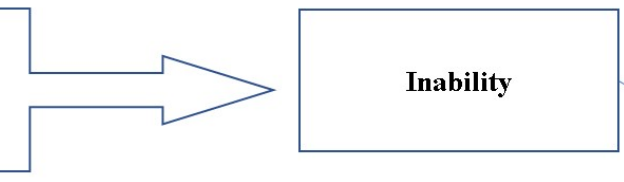

- Resistance to change

- Code of silence

- Lack of whistleblowing policies

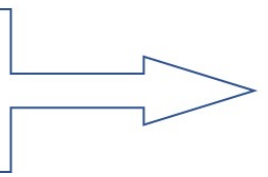

Inertia

\section{Structure-focused}

Tolerance 
Figure Two: First-order Normalization

\section{Why does Corruption persist?}

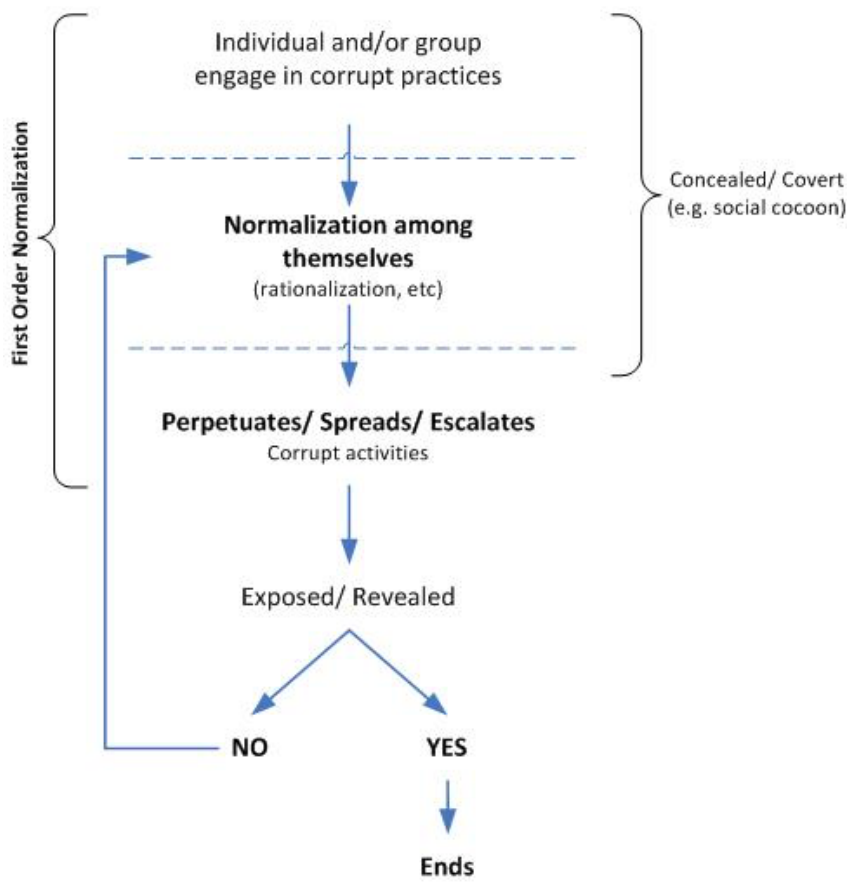


Figure Three: Second-order Normalization

Why does Corruption persist?

Individual and/or group engage in corrupt practices

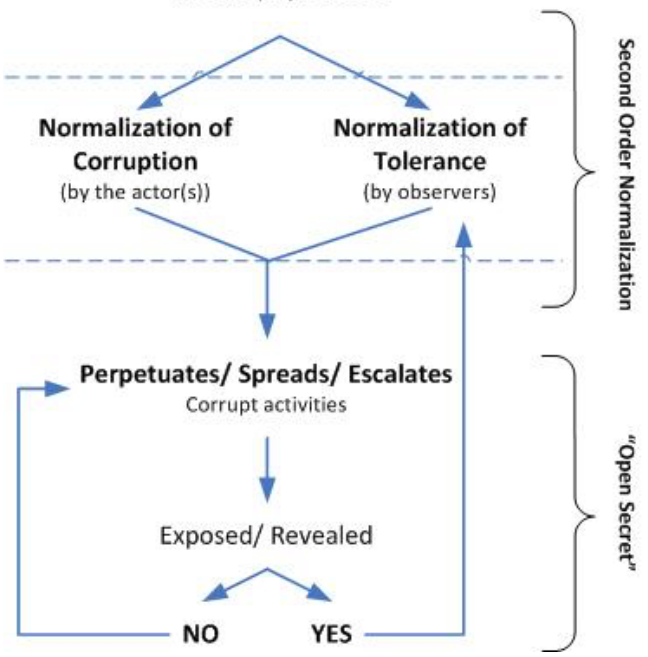




\section{APPENDIX}

Table 1: Listing of Informants (2012-2014)

\begin{tabular}{|c|c|c|c|c|}
\hline Number & $\begin{array}{l}\text { State/Private } \\
\text { Sector }\end{array}$ & Organization & Job Description & $\operatorname{Code}^{2}$ \\
\hline 1 & State & $\begin{array}{l}\text { Ministry of Development, } \\
\text { Competitiveness, Infrastructure, } \\
\text { Transportation and Networks }\end{array}$ & Consultant & $\mathrm{Pb}-1$ \\
\hline 2 & State & Fire Department & Officer & $\mathrm{Pb}-2$ \\
\hline 3 & State & $\begin{array}{l}\text { Manpower Employment } \\
\text { Organization }\end{array}$ & Employee & $\mathrm{Pb}-3$ \\
\hline 4 & State & Hospital & Accountant & $\mathrm{Pb}-4$ \\
\hline 5 & State & $\begin{array}{l}\text { Payment and Control Agency for } \\
\text { Guidance and Guarantee } \\
\text { Community Aid }\end{array}$ & Director & $\mathrm{Pb}-5$ \\
\hline 6 & State & Civil Aviation Authority & $\begin{array}{l}\text { Head of } \\
\text { Department }\end{array}$ & $\mathrm{Pb}-6$ \\
\hline 7 & State & $\begin{array}{l}\text { Management Organization Unit } \\
\text { of Development Programs }\end{array}$ & Economist & $\mathrm{Pb}-7$ \\
\hline 8 & State & Ministry of Defense & Petty Officer & $\mathrm{Pb}-8$ \\
\hline 9 & State & $\begin{array}{l}\text { Hellenic National Council for } \\
\text { Combating Doping }\end{array}$ & Employee & $\mathrm{Pb}-9$ \\
\hline 10 & State & National Library & Employee & $\mathrm{Pb}-10$ \\
\hline 11 & State & $\begin{array}{l}\text { Municipality in District of } \\
\text { Central Macedonia }\end{array}$ & Employee & $\mathrm{Pb}-11$ \\
\hline
\end{tabular}

${ }^{2} \mathrm{~Pb}-\mathrm{X}$ : Public-sector Interview X, Pr-Y: Private Sector Interview Y 


\begin{tabular}{|c|c|c|c|c|}
\hline Number & $\begin{array}{l}\text { State/Private } \\
\text { Sector }\end{array}$ & Organization & Job Description & Code $^{2}$ \\
\hline 12 & State & $\begin{array}{lll}\text { General Chemical State } \\
\text { Laboratory }\end{array}$ & Researcher & $\mathrm{Pb}-12$ \\
\hline 13 & State & State Owned Enterprise & Manager & $\mathrm{Pb}-13$ \\
\hline 14 & State & $\begin{array}{l}\text { Ministry of Development and } \\
\text { Competitiveness }\end{array}$ & Employee & $\mathrm{Pb}-14$ \\
\hline 15 & State & $\begin{array}{l}\text { Payment and Control Agency for } \\
\text { Guidance and Guarantee } \\
\text { Community Aid }\end{array}$ & Manager & $\mathrm{Pb}-15$ \\
\hline 16 & State & Municipality & Employee & $\mathrm{Pb}-16$ \\
\hline 17 & State & Social Security Organization & Employee & $\mathrm{Pb}-17$ \\
\hline 18 & State & State Construction Company & Engineer & $\mathrm{Pb}-18$ \\
\hline 19 & State & Hellenic Postbank & Employee & $\mathrm{Pb}-19$ \\
\hline 20 & State & Ministry of Finance & Employee & $\mathrm{Pb}-20$ \\
\hline 21 & State & Ministry of Finance & Employee & $\mathrm{Pb}-21$ \\
\hline 22 & State & $\begin{array}{ll}\text { Manpower } & \text { Employment } \\
\text { Organization } & \end{array}$ & Employee & $\mathrm{Pb}-22$ \\
\hline 23 & State & Municipality & $\begin{array}{l}\text { Human } \\
\text { Resources }\end{array}$ & $\mathrm{Pb}-23$ \\
\hline 24 & State & Social Security Organization & Employee & $\mathrm{Pb}-24$ \\
\hline 25 & State & $\begin{array}{l}\text { Ministry of Public Order and } \\
\text { Citizen Protection }\end{array}$ & Employee & $\mathrm{Pb}-25$ \\
\hline
\end{tabular}




\begin{tabular}{|c|c|c|c|c|}
\hline Number & $\begin{array}{l}\text { State/Private } \\
\text { Sector }\end{array}$ & Organization & Job Description & Code $^{2}$ \\
\hline 26 & State & Ministry of Finance & Employee & $\mathrm{Pb}-26$ \\
\hline 27 & State & Ministry of Finance & Inspector & $\mathrm{Pb}-27$ \\
\hline 28 & State & $\begin{array}{ll}\text { Manpower } & \text { Employment } \\
\text { Organization } & \end{array}$ & Manager & $\mathrm{Pb}-28$ \\
\hline 29 & State & District of Attica & Manager & $\mathrm{Pb}-29$ \\
\hline 30 & State & $\begin{array}{ll}\text { Agricultural Insurance } \\
\text { Organization }\end{array}$ & Consultant & $\mathrm{Pb}-30$ \\
\hline 31 & Private & Entertainment Company & Manager & Pr-1 \\
\hline 32 & Private & Real Estate Company & Marketing & $\operatorname{Pr}-2$ \\
\hline 33 & Private & Private Practice & Engineer & Pr-3 \\
\hline 34 & Private & Surveys and Polls Company & Researcher & Pr-4 \\
\hline 35 & Private & Mining Company & Geologist & Pr-5 \\
\hline 36 & Private & Civil Engineer & Owner & Pr-6 \\
\hline 37 & Private & $\begin{array}{l}\text { Management and Technology } \\
\text { Consulting Company }\end{array}$ & IT Consultant & Pr-7 \\
\hline 38 & Private & EU Projects Contractor & Manager & Pr-8 \\
\hline 39 & Private & Public Projects & Consultant & Pr-9 \\
\hline 40 & Private & Heavy Industry Equipment & Engineer & Pr-10 \\
\hline 41 & Private & Law Office & Lawyer & Pr-11 \\
\hline 42 & Private & Head-Hunting Multinational & Manager & Pr-12 \\
\hline 43 & Private & Civil Engineer & Owner & Pr-13 \\
\hline
\end{tabular}




\begin{tabular}{|c|c|c|c|c|}
\hline Number & $\begin{array}{l}\text { State/Private } \\
\text { Sector }\end{array}$ & Organization & Job Description & Code $^{2}$ \\
\hline 44 & Private & Construction Company & $\begin{array}{l}\text { Engineer- } \\
\text { Surveyor }\end{array}$ & Pr-14 \\
\hline 45 & Private & Consulting Company & Consultant & Pr-15 \\
\hline 46 & Private & Industrial Management & Manager & Pr-16 \\
\hline 47 & Private & Elevator Installations & Mechanic & Pr-17 \\
\hline 48 & Private & Hotel Management Company & Accountant & Pr-18 \\
\hline 49 & Private & Bank & Employee & Pr-19 \\
\hline 50 & Private & $\begin{array}{l}\text { Private School of Secondary } \\
\text { Education }\end{array}$ & Teacher & Pr-20 \\
\hline 51 & Private & Advertising Agency & Manager & Pr-21 \\
\hline 52 & Private & Web Design & Employee & Pr-22 \\
\hline 53 & Private & Hotel Units & Manager & Pr-23 \\
\hline
\end{tabular}

Table 2: Listing of Informants - Additional Data Collection (2019)

\begin{tabular}{|l|l|l|}
\hline Number & Position & Code \\
\hline 1 & Inspector - Auditor of Public Administration on corruption issues & Rc-1 \\
\hline 2 & Manager of the Public Finance Section of the Bank of Greece's & Rc-2 \\
& Division of Financial Studies & \\
\hline 3 & Senior Executive of the Anti-Money Laundering Authority & Rc-3 \\
\hline 4 & Senior manager of a major European Multinational corporation & Rc-4 \\
\hline 5 & Senior Partner in a Greek Law firm & Rc-5 \\
\hline
\end{tabular}




\section{References}

Aleksander, A., \& Stachowicz-Stanusch, A. (2008). Corporate brand reputation rebuilding after the company's crisis. Academy of Management Review, 33(3): 730-749.

Anand, V., Ashforth, B. E., \& Joshi, M. (2004). Business as usual: The acceptance and perpetuation of corruption in organizations. The Academy of Management Executive, 18(2): $39-53$.

Anastasakis, O. (2005). The Europeanization of the Balkans. Journal of World Affairs, 12: 77. Anastasakis, O., Bechev, D., \& Vrousalis, N. (2009). Greece in the Balkans: Memory, Conflict and Exchange: Cambridge Scholars.

Ashforth, B. E., \& Anand, V. (2003). The normalization of corruption in organizations. Research in organizational behavior, 25: 1-52.

Athanasouli, D., Goujard, A., \& Sklias, P. (2012). Corruption and firm performance: Evidence from Greek firms. International Journal of Economic Sciences and Applied Research, 5(2), 43-67.

Bandura, A. (1999). Moral disengagement in the perpetration of inhumanities. Personality and social psychology review, 3(3): 193-209.

Bandura, A., Barbaranelli, C., Caprara, G. V., \& Pastorelli, C. (1996). Mechanisms of moral disengagement in the exercise of moral agency. Journal of personality and social psychology, 71(2): 364 .

BBC. (2012). Greece 'most corrupt' EU country, new survey reveals.

Blundo, G., de-Sardan, J. P. O., Arifari, N. B., \& Alou, M. T. (2013). Everyday corruption and the state: Citizens and public officials in Africa. Zed Books Ltd.

Brief, A. P., Buttram, R. T., \& Dukerich, J. M. (2001). Collective corruption in the corporate world: Toward a process model. Groups at work: Theory and research, 471: 499. 
Charmaz, K. (2008). Constructionism and the grounded theory method. Handbook of contructionist research, 1: 397-412.

Collins, J. D., Uhlenbruck, K., \& Rodriguez, P. (2009). Why firms engage in corruption: A top management perspective. Journal of Business Ethics, 87(1), 89-108.

DiFonzo, N., \& Bordia, P. (2007). Rumor psychology: Social and organizational approaches. American Psychological Association.

Elkind, P., \& McLean, B. (2004). The Smartest guys in the room: the amazing rise and scandalous fall of enron: Penguin, Sept.

Einwiller, S. A., \& Kamins, M. A. (2008). Rumor has it: the moderating effect of identification on rumor impact and the effectiveness of rumor refutation 1. Journal of applied social psychology, 38(9), 2248-2272.

EU Commission. (2014). Report from the commission to the council and the European parliament-EU anti-corruption report.

Fleming, P., \& Zyglidopoulos, S. C. (2009). Charting corporate corruption: agency, structure and escalation: Edward Elgar Publishing.

Flyvbjerg, B. (2006). 1.10 making organization research matter: Power, values and phronesis, The Sage handbook of organization studies: 370.

Gardberg, N. A., Sampath, V., \& Rahman, N.( 2012). Corruption and corporate reputation: The paradox of buffering and suffering. Paper presented at the Academy of Management Proceedings.

Getz, K. A., \& Volkema, R. J. (2001). Culture, perceived corruption, and economics: A model of predictors and outcomes. Business \& society, 40(1), 7-30.

Gioia, D. A., Corley, K. G., \& Hamilton, A. L. (2013). Seeking qualitative rigor in inductive research: Notes on the Gioia methodology. Organizational research methods, 16(1), 15-31. 
Greil, A. L., \& Rudy, D. R. (1984). Social cocoons: Encapsulation and identity transformation organizations. Sociological Inquiry, 54(3): 260-278.

Greve, C. (2015). Ideas in public management reform for the 2010s. Digitalization, value creation and involvement. Public Organization Review, 15(1), 49-65.

Greve, H. R., Palmer, D., \& Pozner, J. E. (2010). Organizations gone wild: The causes, processes, and consequences of organizational misconduct. The Academy of Management Annals, 4(1): 53-107.

IMF. (2016). Corruption: Costs and Mitigating Strategies, Staff Discussion Note. Washington, DC, USA: IMF.

Jancsics, D. (2014). Interdisciplinary perspectives on corruption. Sociology Compass, 8(4), $358-372$.

Jávor, I., \& Jancsics, D. (2016). The role of power in organizational corruption: an empirical study. Administration \& Society, 48(5), 527-558.

Kanellopoulos, K., Kousoulakos, I., Rapanos, V. (1995). Shadow economy and tax evasion: Measurements and economic impacts, Report KEPE, no. 15, Athens: The Centre of Planning and Economic Research (in Greek).

Karakas, F., \& Sarigollu, E. (2012). Benevolent leadership: Conceptualization and construct development. Journal of Business Ethics, 108(4), 537-553

Katsios S. (2015). The shadow economy and corruption in Greece. South-Eastern Europe Journal of Economics, 4(1).

Kish-Gephart, J. J., Harrison, D. A., \& Treviño, L. K. (2010). Bad apples, bad cases, and bad barrels: meta-analytic evidence about sources of unethical decisions at work. Journal of Applied Psychology, 95(1): 1.

Kollintzas, T. (2000), The Inertia of the Status Quo, in Kollintzas, T. (Ed.), The Inertia of the Status Quo and other Pathogenic Causes of the Greek Economy, Athens, Kritiki (in Greek) 
Koutsoukis, K. S. (2003). Political Corruption in Greece, Corruption in Contemporary Politics: 24-36: Springer.

Kuppens, P., Allen, N. B., \& Sheeber, L. B. (2010). Emotional inertia and psychological maladjustment. Psychological science, 21(7), 984-991.

Lyberaki, A., \& Paraskevopoulos, C. J. (2002). Social capital measurement in Greece. Paper presented at the International Conference of the Organisation for Economic Co-operation and Development (OECD), London.

Manesiotis V. (1991), Tax evasion in Greece, in Tatsios, N (Ed.) Public Finance in Greece. Smbilia Publications, Athens (in Greek)

Martin, A. W., Lopez, S. H., Roscigno, V. J., \& Hodson, R. (2013). Against the rules: Synthesizing types and processes of bureaucratic rule-breaking. Academy of Management Review, 38(4): 550-574.

McLean, B., \& Elkind, P. (2004). The Smartest Guys in the Room: The Amazing Rise and Scandalous Fall of Enron: Penguin Books, Limited.

Misangyi, V. F., Weaver, G. R., \& Elms, H. (2008). Ending corruption: The interplay among institutional logics, resources, and institutional entrepreneurs. Academy of Management Review, 33(3), 750-770.

Oliver, C. (1991). Strategic responses to institutional processes. Academy of management review, 16(1): 145-179.

Palazzo, G., Krings, F., \& Hoffrage, U. (2012). Ethical blindness. Journal of business ethics, 109(3): 323-338.

Palmer, D. (2008). Extending the process model of collective corruption. Research in Organizational Behavior, 28: 107-135.

Palmer, D. A. (2013). The New Perspective on Organizational Wrongdoing. California Management Review, 56(1): 5-23. 
Pavlopoulos, P. (1987). 'Shadow economy in Greece: a first quantitative demarcation', Athens: Foundation for Economic \& Industrial Research.

Peeples, D. K., Stokes, P., \& Wingfield, S. S. (2009). When the whistle is blown: Legal defenses and practical guidelines for managing reports of organizational misconduct. Business \& Society, 48(4), 467-488.

Peterson, R. A., \& Merunka, D. R. (2014). Convenience samples of college students and research reproducibility. Journal of Business Research, 67(5), 1035-1041.

Strauss, A., \& Corbin, J. (1990). Basics of qualitative research: Sage publications.

Suchman, M. C. (1995). Managing legitimacy: Strategic and institutional approaches. Academy of management review, 20(3): 571-610.

Sutherland, E. H. (1949). White collar Crime. New York: Dryden Press.

Sykes, G. M., \& Matza, D. (1957). Techniques of neutralization: A theory of delinquency. American sociological review, 22(6): 664-670.

Tatsos, N. (2001), Shadow economy and tax evasion in Greece, Athens: Institute of Economic and Industrial Research (in Greek)

Telloglou, T. (2009). The network: the Siemens file. Athens, Skai (in Greek).

Tenbrunsel, A. E., \& Messick, D. M. (2004). Ethical fading: The role of self-deception in unethical behavior. Social Justice Research, 17(2): 223-236.

Toffler, B. L., \& Reingold, J. (2004). Final Accounting: Ambition, Greed, and the Fall of Arthur Andersen: Currency/Doubleday.

Transparency-International. (2018). In T. Internatrional (Ed.), Vol. 2019: Western Europe and EU: Stagnating anti-corruption efforts and weakening democratic institutions. Transparency International.

Transparency-International. (2011). The Global Coalition against Corruption: Transparency International. 
Yu, K.-H., Kang, S.-D., \& Rhodes, C. (2018). The Partial Organization of Networked Corruption. Business \& Society: 0007650318775024.

Zhuang, J., Thomas, S., \& Miller, D. L. (2005). Examining culture's effect on whistle-blowing and peer reporting. Business \& society, 44(4), 462-486.

Zimbardo, P. (2011). The Lucifer effect: How good people turn evil: Random House.

Zyglidopoulos, S. C., \& Fleming, P. J. (2008). Ethical distance in corrupt firms: How do innocent bystanders become guilty perpetrators? Journal of Business Ethics, 78(1-2): 265-274. 